\title{
Evaluation of nutrient excretion and retention in broilers submitted to different nutritional strategies
}

\section{-Author(s)}

Graña AL

Tavernari $\mathrm{FC}^{2}$

Lelis $\mathrm{GR}^{1}$

Albino $\mathrm{LFT}^{3}$

Rostagno HS

Gomes $\mathrm{PC}^{3}$

Graduate Program in Animal Sciences UFV

2 Embrapa Swine and Poultry Researcher

Department of Animal Science - UFV

\section{nMail Adress}

*Corresponding author e-mail address

E-mail: alfredo_lora@hotmail.com

\section{-Keywords}

Enzyme, phosphorus, organic trace minerals, ideal protein.

\begin{abstract}
An experiment was carried out to evaluate the effects of different nutritional strategies on nitrogen $(\mathrm{N})$, phosphorus $(\mathrm{P})$ and calcium $(\mathrm{Ca})$ balance and on copper $(\mathrm{Cu})$, manganese $(\mathrm{Mn})$ and zinc ( $\mathrm{Zn})$ excretion in broilers during the periods of 1 to 21 days and 1 to 46 days of age. Four hundred male Cobb-500 broilers were used. A randomized block experimental design was applied, including five treatments with eight replicates of 10 birds each. A five-phase feeding program was adopted (1-8, 9-21, 22-33, 34-40 and 41-46 days of age). Treatments consisted of a control diet (C) with typical protein level and low amino acid supplementation; a reduced-protein diet supplemented with synthetic amino acids formulated on ideal protein concept (IP); $\mathrm{C}$ with phytase $(\mathrm{C}+\mathrm{PHY})$ supplementation; $\mathrm{C}$ with inorganic-organic mineral supplementation $(\mathrm{C}+\mathrm{MIN})$; and a diet formulated on ideal protein (IP) basis, and supplemented with phytase and organic and inorganic minerals $(\mathrm{IP}+\mathrm{PHY}+\mathrm{MIN})$. IP and IP+PHY+MIN diets reduced nitrogen excretion in 13.6 and $13.1 \%$ respectively, and promoted the same nitrogen retention ( $\mathrm{g} / \mathrm{bird}$ ) and retention efficiency as compared to the diet with typical crude protein level. $\mathrm{C}+\mathrm{PHY}$ and IP+PHY+MIN reduced phosphorus, calcium and manganese excretion, and improved phosphorus retention. $\mathrm{C}+\mathrm{MIN}$ and $\mathrm{IP}+\mathrm{PHY}+\mathrm{MIN}$ reduced manganese excretion, but did not influence copper or zinc excretion.
\end{abstract}

\section{INTRODUCTION}

Brazil is the world's biggest chicken meat exporter and one of the largest poultry producers. However, a downside to this excellent performance is that poultry waste became a significant environmental issue in regions where there is a high concentration of poultry farms.

Poultry excreta contain significant N, Ca, P, Cu, Mn, and Zn levels, which contribute to environmental pollution, particularly of water sources (Payne, 1998; Paterson, 2002).

Poultry nutritionists have sought alternatives to formulate more efficient feeds, reducing production costs and environmental pollution. The use of nutritional strategies, such as formulation of low-protein diets with synthetic amino acid supplementation and dietary addition of enzymes and organic trace minerals, has helped to reduce the impact of the excretion of potentially polluting elements in the environment (Ferket et al., 2002).

The aim of this study was to evaluate the effect of different nutritional strategies, including the use of synthetic amino acids, phytase, and organic trace minerals on nutrient ( $N, \mathrm{Ca}, \mathrm{P}, \mathrm{Cu}, \mathrm{Mn}$, and $\mathrm{Zn}$ ) retention and excretion in 21- and 46-day-old broilers. 


\section{MATERIALS AND METHODS}

The experiment was carried out at the Poultry Sector of the Animal Science Department of the Federal University of Viçosa, Brazil. In total, 400 one-day-old male Cobb-500 broilers, with 43.63 $\mathrm{g}$ initial body weight. were used. Chicks were vaccinated in the hatchery against fowl pox and Marek's disease.

During the entire experimental period, birds were housed in metal battery cages arranged in two levels and placed in a room with an area of $68.0 \mathrm{~m}^{2}$ and $2.8 \mathrm{~m}$ height.

The room microclimate was created using polyurethane curtains and one 250w infrared lamp per pen in the aisle. As bird temperature requirement was reduced, lamp height and curtain opening were regulated. Curtains were removed when birds were three weeks old.

Water and feed were supplied ad libitum during the entire experimental period. House internal temperature and relative humidity were determined using three thermometers and one hygrometer, both with maximum-minimum measurements, placed at different locations inside the house at birds' height. Average temperature and relative humidity recorded during the experiment were $28.8^{\circ} \mathrm{C}(25.3$ and $31.3^{\circ} \mathrm{C}$ minimum and maximum temperature, respectively) and $71.3 \%$ relative humidity $(63.5 \%$ and $79.2 \%$ minimum and maximum relative humidity, respectively) for the period of 1 to 21 days; and $24.7^{\circ} \mathrm{C}\left(20.8\right.$ and $28.7^{\circ} \mathrm{C}$ minimum and maximum temperature, respectively) and $75.2 \%$ relative humidity $(57.8 \%$ and $92.7 \%$ minimum and maximum relative humidity, respectively) for the period of 22 to 46 days of age.

A randomized block experimental design was applied, including five treatments with eight replicates of 10 birds each. For better utilization of cage space, two birds were removed at the end of each experimental phase. Treatments consisted of a control diet (C), with typical protein level and low amino acid supplementation; a reduced crude protein diet supplemented with synthetic amino acids and formulated on the ideal protein concept (IP); C with phytase (C+PHY) supplementation; C with mineral supplementation (C+MIN 40\% organic minerals and $50 \%$ inorganic minerals) and a feed combining nutritional strategies (formulation based on ideal protein concept, and supplemented with phytase and organic and inorganic minerals) $(\mathrm{IP}+\mathrm{PHY}+\mathrm{MIN})$. It was assumed that $40 \%$ organic minerals were equivalent to $50 \%$ inorganic minerals according to Ammerman et al. (1995).

A five-phase feeding program was applied: pre-starter (1-8 days); starter (8-21 days); grower I (22-33 days); grower II (34-40 days); finisher (41-46 days).

The phytase enzyme was produced by the yeast schizosaccharomyces pombe at a concentration of 5000 FTU/g of product, and supplemented at a dose of $100 \mathrm{~g} /$ ton (500 FTU/kg diet). As phytase increases calcium and phosphorus availability in feeds, its nutritional value to supply the requirements of these minerals was considered, and the feed with phytase supplied the same calcium and phosphorus levels as the control feed.

A mineral supplement containing only inorganic minerals was formulated for diets C, IP and C+PHY (Table 1), and an inorganic-organic mineral supplement was formulated for diets C+MIN and IP+PHY+MIN (Table 2).

Table 1 - Composition of the inorganic mineral supplement and amount of mineral in the supplement $(\mathrm{g} / \mathrm{kg})$ and in the diets $(C, I P$ and $\mathrm{C}+\mathrm{PHY}$ ) per feeding phase ( $\mathrm{kg} / \mathrm{ton})$

\begin{tabular}{lccccc}
\hline $\begin{array}{l}\text { Mineral source } \\
\text { (concentration) }\end{array}$ & Source, \% & $\begin{array}{c}\text { Mineral, } \\
\mathrm{g} / \mathrm{kg} \\
\text { supplement }\end{array}$ & $\begin{array}{c}\text { Pre-st/ } \\
\text { starter, mg/ } \\
\mathrm{kg}^{1}\end{array}$ & $\begin{array}{c}\text { Grower } \\
\mathrm{mg} / \\
\mathrm{kg}^{2}\end{array}$ & $\begin{array}{c}\text { Finisher } \\
\mathrm{mg} / \mathrm{kg}^{3}\end{array}$ \\
\hline Cu sulfate (35\%) & 2.86 & 10.00 & 11.00 & 10.00 & 7.50 \\
\hline Fe sulfate (30\%) & 16.67 & 50.00 & 55.00 & 50.00 & 37.50 \\
Ca iodate (63\%) & 0.13 & 0.80 & 0.88 & 0.80 & 0.60 \\
Mn sulfate (26\%) & 25.00 & 65.00 & 71.50 & 65.00 & 48.80 \\
Na selenide (45\%) & 0.07 & 0.30 & 0.33 & 0.30 & 0.23 \\
\hline Zn sulfate (35\%) & 17.14 & 60.00 & 66.00 & 60.00 & 45.00 \\
Limestone (38.4\%) & 38.14 & 146.40 & 180.40 & 146.40 & 109.80 \\
\hline Total & 100.00 & & & & \\
\hline
\end{tabular}

${ }^{1}$ Pre-starter and Starter, 1.1 kg/ton; ${ }^{2}$ Grower (1 and 2), 1.0 kg/ton; ${ }^{3}$ Finisher, 0.75 kg/ton

Table 2 - Composition of the organic mineral supplement and amount of mineral in the supplement $(\mathrm{g} / \mathrm{kg})$ and in the diets $(\mathrm{C}+\mathrm{MIN}$ and IP+PHY+MIN)

\begin{tabular}{lccccc}
\hline $\begin{array}{l}\text { Mineral source } \\
\text { (concentration) }\end{array}$ & Source, \% & $\begin{array}{c}\text { Mineral, } \\
\text { g/kg } \\
\text { supplement }\end{array}$ & $\begin{array}{c}\text { Pre-st/starter, } \\
\mathrm{mg} / \mathrm{kg}^{1}\end{array}$ & $\begin{array}{c}\text { Grower } \\
\mathrm{mg} / \mathrm{kg}^{2}{ }^{2}\end{array}$ & $\begin{array}{c}\text { Finisher } \\
\mathrm{mg} / \mathrm{kg}^{3}\end{array}$ \\
\hline Cu sulfate (35\%) & 1.43 & 5.00 & 5.50 & 5.00 & 3.75 \\
\hline Fe sulfate (30\%) & 16.67 & 50.00 & 5.50 & 50.00 & 37.50 \\
Ca iodate (63\%) & 0.13 & 0.80 & 0.88 & 0.80 & 0.60 \\
Mn sulfate (26\%) & 12.50 & 32.50 & 35.80 & 32.50 & 24.40 \\
Na selenide (45\%) & 0.07 & 0.30 & 0.33 & 0.30 & 0.23 \\
Zn sulfate (35\%) & 8.57 & 30.00 & 33.00 & 30.00 & 22.50 \\
Organic Cu (15\%) & 1.33 & 2.00 & 2.20 & 2.00 & 1.50 \\
Organic Mn (13\%) & 10.00 & 13.00 & 14.30 & 13.00 & 9.75 \\
Organic Zn (16\%) & 7.50 & 12.00 & 13.20 & 12.00 & 9.00 \\
Organic Cu (21\%) & 0.95 & 2.00 & 2.20 & 2.00 & 1.50 \\
Organic Mn (21\%) & 6.19 & 13.00 & 14.30 & 13.00 & 9.75 \\
Organic Zn (21\%) & 5.71 & 12.00 & 13.20 & 12.00 & 9.00 \\
Limestone (38.4\%) & 28.95 & 74.10 & 81.50 & 74.10 & 55.60 \\
\hline Total & 100.00 & & & & \\
\hline
\end{tabular}

${ }^{1}$ Pre-starter and Starter $1.1 \mathrm{~kg} /$ ton; ${ }^{2}$ Grower (1 and 2), $1.0 \mathrm{~kg} /$ ton; ${ }^{3}$ Finisher, $0.75 \mathrm{~kg} /$ ton 
The composition of the organic trace minerals used in the inorganic-organic supplements is shown in Table 3.

Table 3 - Composition of the commercial organic trace mineral products used in the experimental diets

\begin{tabular}{lcccccc}
\hline \multirow{2}{*}{ Nutrients } & \multicolumn{6}{c}{ Organic Trace Minerals } \\
\cline { 2 - 7 } & $\begin{array}{l}\mathrm{Zn}= \\
16 \%\end{array}$ & $\mathrm{Mn}=$ & $\mathrm{Cu}=$ & $\mathrm{Zn}=$ & $\mathrm{Mn}=$ & $\mathrm{Cu}=$ \\
& $13 \%$ & $15 \%$ & $21 \%$ & $21 \%$ & $21 \%$ \\
\hline AME, kcal/kg & 3823 & 3727 & 3727 & 286 & 361 & 301 \\
Crude protein, \% & 47.0 & 45.8 & 45.8 & 22.6 & 28.5 & 23.8 \\
L-methionine, \% & 80.0 & 78.0 & 78.0 & 0.0 & 0.0 & 0.0 \\
Glycine, \% & 0.0 & 0.0 & 0.0 & 19.0 & 24.0 & 20.0 \\
Sulfur & 17.3 & 16.8 & 16.8 & 0.0 & 0.0 & 0.0 \\
\hline
\end{tabular}

Feeds were based on corn and soybean meal. In the pre-starter diet, fish meal and corn gluten meal were added. Nutritional requirements in each phase followed the recommendations of Rostagno et al. (2005). Tables 4 to 8 show the composition of the experimental diets for each feeding phase.

Table 4 - Chemical composition of pre-starter (1-7 days) experimental diets

\begin{tabular}{lccccc}
\hline & C & IP & C+PHY & C+MIN & IP+PHY+MIN \\
\hline Crude Protein, \% & 26.00 & 24.50 & 26.00 & 26.00 & 24.50 \\
AME, Kcal/Kg & 2950 & 2950 & 2950 & 2950 & 2950 \\
Calcium, \% & 0.939 & 0.939 & 0.829 & 0.939 & 0.829 \\
Avail. phosphorus, \% & 0.470 & 0.470 & 0.350 & 0.470 & 0.350 \\
\hline Dig. Lysine, \% & 1.330 & 1.330 & 1.330 & 1.330 & 1.330 \\
Dig. Met + Cys, \% & 0.944 & 0.944 & 0.944 & 0.944 & 0.944 \\
Dig. Threonine, \% & 0.865 & 0.865 & 0.865 & 0.865 & 0.865 \\
Dig. Tryptophan, \% & 0.261 & 0.242 & 0.262 & 0.261 & 0.241 \\
Dig. Arginine, \% & 1.575 & 1.461 & 1.576 & 1.575 & 1.459 \\
Dig. Valine, \% & 1.061 & 0.998 & 1.063 & 1.061 & 0.998 \\
\hline
\end{tabular}

Table 5 - Chemical composition of starter (8-21 days) experimental diets

\begin{tabular}{lccccc}
\hline & C & IP & C+PHY & C+MIN & IP+PHY+MIN \\
\hline Crude Protein, \% & 22.06 & 20.77 & 22.06 & 22.06 & 20.77 \\
AME, Kcal/Kg & 3000 & 3000 & 3000 & 3000 & 3000 \\
Calcium, \% & 0.884 & 0.884 & 0.774 & 0.884 & 0.774 \\
\hline Avail. phosphorus, \% & 0.442 & 0.442 & 0.322 & 0.442 & 0.322 \\
\hline Dig. Lysine, \% & 1.146 & 1.146 & 1.146 & 1.146 & 1.146 \\
\hline Dig. Met + Cys, \% & 0.814 & 0.814 & 0.814 & 0.814 & 0.814 \\
\hline Dig. Threonine, \% & 0.745 & 0.745 & 0.745 & 0.745 & 0.745 \\
Dig. Tryptophan, \% & 0.245 & 0.227 & 0.245 & 0.245 & 0.227 \\
Dig. Arginine, \% & 1.429 & 1.329 & 1.430 & 1.429 & 1.327 \\
Dig. Valine, \% & 0.921 & 0.865 & 0.922 & 0.921 & 0.865 \\
\hline
\end{tabular}

Table 6 - Chemical composition of grower 1 (22-33 days) experimental diets

\begin{tabular}{lccccc}
\hline & C & IP & C+PHY & C+MIN & IP+PHY+MIN \\
\hline Crude Protein, \% & 21.00 & 19.83 & 21.00 & 21.00 & 19.83 \\
AME, Kcal/Kg & 3100 & 3100 & 3100 & 3100 & 3100 \\
Calcium, \% & 0.824 & 0.824 & 0.714 & 0.824 & 0.714 \\
Avail. phosphorus, \% & 0.411 & 0.411 & 0.291 & 0.411 & 0.291 \\
Dig. Lysine, \% & 1.073 & 1.073 & 1.073 & 1.073 & 1.073 \\
Dig. Met + Cys, \% & 0.773 & 0.773 & 0.773 & 0.773 & 0.773 \\
Dig. Threonine, \% & 0.697 & 0.697 & 0.697 & 0.697 & 0.697 \\
Dig. Tryptophan, \% & 0.232 & 0.216 & 0.231 & 0.232 & 0.215 \\
Dig. Arginine, \% & 1.352 & 1.261 & 1.350 & 1.352 & 1.259 \\
Dig. Valine, \% & 0.877 & 0.826 & 0.876 & 0.877 & 0.826 \\
\hline
\end{tabular}

Table 7 - Chemical composition of grower 2 (34-40 days) experimental diets

\begin{tabular}{lccccc}
\hline & C & IP & C+PHY & C+MIN & IP+PHY+MIN \\
\hline Crude Protein, \% & 20.00 & 18.81 & 20.00 & 20.00 & 18.81 \\
AME, Kcal/Kg & 3150 & 3150 & 3150 & 3150 & 3150 \\
Calcium, \% & 0.763 & 0.763 & 0.653 & 0.763 & 0.653 \\
Avail. phosphorus, \% & 0.380 & 0.380 & 0.260 & 0.380 & 0.260 \\
Dig. Lysine, \% & 1.017 & 1.017 & 1.017 & 1.017 & 1.017 \\
Dig. Met + Cys, \% & 0.732 & 0.732 & 0.732 & 0.732 & 0.732 \\
Dig. Threonine, \% & 0.661 & 0.661 & 0.661 & 0.661 & 0.661 \\
Dig. Tryptophan, \% & 0.219 & 0.202 & 0.218 & 0.219 & 0.202 \\
Dig. Arginine, \% & 1.277 & 1.184 & 1.275 & 1.277 & 1.182 \\
Dig. Valine, \% & 0.834 & 0.783 & 0.834 & 0.834 & 0.783 \\
\hline
\end{tabular}

Table 8 - Chemical composition of finisher (41-46 days) experimental diets

\begin{tabular}{lccccc}
\hline & C & IP & C+PHY & C+MIN & IP+PHY+MIN \\
\hline Crude Protein, \% & 19.16 & 17.95 & 19.21 & 19.16 & 17.95 \\
AME, Kcal/Kg & 3200 & 3200 & 3200 & 3200 & 3200 \\
Calcium, \% & 0.728 & 0.728 & 0.618 & 0.728 & 0.618 \\
Avail. phosphorus, \% & 0.363 & 0.363 & 0.243 & 0.363 & 0.243 \\
Dig. Lysine, \% & 0.970 & 0.970 & 0.970 & 0.970 & 0.970 \\
Dig. Met + Cys, \% & 0.698 & 0.698 & 0.698 & 0.698 & 0.698 \\
Dig. Threonine, \% & 0.631 & 0.631 & 0.631 & 0.631 & 0.631 \\
Dig. Tryptophan, \% & 0.208 & 0.191 & 0.208 & 0.208 & 0.191 \\
Dig. Arginine, \% & 1.215 & 1.121 & 1.216 & 1.215 & 1.118 \\
Dig. Valine, \% & 0.799 & 0.747 & 0.801 & 0.799 & 0.747 \\
\hline
\end{tabular}

Trays lined with plastic were placed under the cage for excreta collection. Excreta were identified, weighed, and stored in a freezer until subsequent nitrogen $(\mathrm{N})$, phosphorus $(\mathrm{P})$, calcium $(\mathrm{Ca})$, manganese $(\mathrm{Mn})$, zinc (Zn) and copper (Cu) analyses

Nitrogen content was determined using the Kjedhal method. Phosphorus, calcium, potassium, copper, manganese and zinc contents were calculated after samples were submitted to nitric perchloric digestion, obtaining substrate for mineral determination. Calcium, copper, manganese and zinc contents were estimated by atomic absorption and phosphorus content by the colorimetric method. 
All analyses were calculated in duplicate at the Animal Nutrition Laboratory of the Department of Animal Science of Federal University of Viçosa, Brazil, using the methodology described by Silva (1990).

Nitrogen, $\mathrm{P}$ and $\mathrm{Ca}$ balances, and trace mineral excretion ( $\mathrm{Cu}, \mathrm{Mn}$ and $\mathrm{Zn}$ ) were calculated for 21and 46-d-old broilers. Nutrient balance was calculated considering the amount of nutrient intake (g/bird), determined considering analyzed nutrient content in the diet, feed intake and nutrient excretion (g/bird) at the end of each phase. Nutrient excretion (g/bird) was determined according to analyzed nutrient content in the excreta produced at the end of each phase. Nutrient retention ( $\mathrm{g} / \mathrm{bird}$ ) was calculated as nutrient intake (g/bird) minus nutrient excretion (g/bird). Nutrient retention (\%) indicates the percentage of nutrient retained by the bird as a function of nutrient intake, and it was calculated as follows:

Nutrient retention $(\%)=[$ nutrient retention $(\mathrm{g} / \mathrm{bird})$ / nutrient intake (g/bird) ${ }^{*} 100$

Nitrogen, $\mathrm{P}$ and $\mathrm{Ca}$ balance and trace mineral excretion ( $\mathrm{Cu}, \mathrm{Mn}$ and $\mathrm{Zn}$ ) results were submitted to analysis of variance. Means were compared to the control treatment using the t-test (contrasts) at 5\% probability level. Data were processed using SAEG (Sistema de Análises Estatísticas e Genéticas) statistical package (UFV, 2000).

\section{RESULTS AND DISCUSSION}

Table 9 shows nitrogen balance results during the period of 1 to 21 days of age of broilers submitted to different nutritional strategies.

Table 9 - Nitrogen balance results of 1- to 21-d-old broilers submitted to different nutritional strategies

\begin{tabular}{lcccc}
\hline Treatments & $\begin{array}{c}\text { N intake, g/ } \\
\text { bird }\end{array}$ & $\begin{array}{c}\text { N excretion, } \\
\text { g/bird }\end{array}$ & $\begin{array}{c}\text { N retention, } \\
\text { g/bird }\end{array}$ & $\begin{array}{c}\text { N retention, } \\
\%\end{array}$ \\
\hline Control (C') & 46.4 & 17.9 & 28.5 & 61.5 \\
IP $^{2}$ & $43.6^{*}$ & $15.5^{*}$ & 28.1 & $64.4^{*}$ \\
C+PHY & 46.5 & $16.3^{*}$ & $30.2^{*}$ & $65.0^{*}$ \\
C+MIN & 46.9 & $16.7^{*}$ & $30.3^{*}$ & $64.5^{*}$ \\
\hline IP+PHY+MIN & $44.3^{*}$ & $15.5^{*}$ & 28.9 & $65.1^{*}$ \\
\hline ANOVA & 0.001 & 0.001 & 0.013 & 0.017 \\
\hline CV \% & 2.6 & 5.9 & 5.0 & 3.5 \\
\hline
\end{tabular}

${ }^{1} \mathrm{C}=$ Typical crude protein levels; ${ }^{2} \mathrm{P}=$ ideal protein; ${ }^{3} \mathrm{PHY}=$ Phytase; ${ }^{4} \mathrm{Min}=50 \%$ inorganic minerals $+40 \%$ organic trace minerals.

Means followed by * in the same column are different from the control treatment by the $t$ test at $5 \%$ probability level.

Compared with the control birds $(C)$, broilers fed the IP diet presented $6.0 \%$ reduction $(p<0.05)$ in $\mathrm{N}$ intake, which resulted in $13.2 \%$ reduction $(p<0.05)$ in $\mathrm{N}$ excretion. Considering that the average protein reduction between the pre-starter ( 1 to 8 days) and the starter (8 to 21 days) diets was $1.4 \%$, a $9.4 \%$ reduction in $\mathrm{N}$ excretion per unit of crude protein was obtained. Similar results were obtained by Rodrigues (2006), who observed $8 \%$ reduction in nitrogen excretion in broilers between 1 and 21 days of age.

The excellent digestibility and availability of the synthetic amino acids supplemented to the reducedprotein diet (IP) prevented excessive $\mathrm{N}$ excretion, resulting in equal ( $p>0.05) \mathrm{N}$ retention $(\mathrm{g} / \mathrm{bird})$ and increased $(P<0.05) \mathrm{N}$ retention efficiency in $4.7 \%$ as compared to the broilers fed the control diet.

The diet containing phytase $(\mathrm{C}+\mathrm{PHY})$ did not influence $(p>0.05) \mathrm{N}$ intake, but it was better than the $C$ diet because it reduced $(p<0.05) \mathrm{N}$ excretion in $9.1 \%$ and increased $\mathrm{N}$ retention (g/bird and $\%$ ) in $6.0 \%$ and $5.7 \%$, respectively. Phytase is also known for releasing amino acids chelated with phytate, thereby contributing to increase nitrogen retention and to reduce nitrogen excretion in poultry (Lan et al., 2002; Viveiros et al., 2002; Rutherfurd et al., 2004).

The diet supplemented with inorganic-organic minerals $(C+M I N)$ did not influence $(p>0.05) \mathrm{N}$ intake, but was more efficient than the control diet $(C)$, as it reduced $(p<0.05) \mathrm{N}$ excretion in $6.8 \%$ and increased $\mathrm{N}(\mathrm{g} / \mathrm{bird}$ and $\%)$ in $6.1 \%$ and $4.9 \%$, respectively.

The diet with the combination of different nutritional strategies $(\mathrm{IP}+\mathrm{PHY}+\mathrm{MIN})$ improved the absorption of amino acids in the gastrointestinal tract, reducing $\mathrm{N}$ excretion in $4.5 \%$, and increased the efficiency of $\mathrm{N}$ retention $(p<0.05)$ in $5.9 \%$ as compared to $C$.

Table 10 presents nitrogen balance data of broilers during the period of 1 to 46 days of age, submitted to different nutritional strategies.

Table 10 - Nitrogen balance results of 1 - to 46-d-old broilers submitted to different nutritional strategies

\begin{tabular}{lcccc}
\hline Treatment & $\begin{array}{c}\text { N intake, g/ } \\
\text { bird }\end{array}$ & $\begin{array}{c}\text { N excretion, } \\
\text { g/bird }\end{array}$ & $\begin{array}{c}\text { N retention, } \\
\text { g/bird }\end{array}$ & $\begin{array}{c}\text { N retention, } \\
\%\end{array}$ \\
\hline Control (C $\left.{ }^{1}\right)$ & 171.4 & 65.4 & 105.9 & 61.8 \\
\hline IP $^{2}$ & $161.6^{*}$ & $56.9^{*}$ & 104.7 & 64.7 \\
C+PHY & 173.5 & 61.8 & 111.7 & 64.4 \\
C+MIN & 171.6 & 61.7 & 109.9 & 64.1 \\
IP+PHY+MIN & $160.4^{*}$ & $56.5^{*}$ & 103.9 & 64.7 \\
\hline ANOVA & 0.001 & 0.001 & $\mathrm{~ns}^{5}$ & $\mathrm{~ns}$ \\
\hline CV \% & 3.6 & 6.3 & 6.2 & 3.8 \\
\hline
\end{tabular}

${ }^{1} \mathrm{C}=$ Typical crude protein levels; ${ }^{2} \mathrm{IP}=$ ideal protein; ${ }^{3} \mathrm{PHY}=$ Phytase; ${ }^{4} \mathrm{Min}=50 \%$ inorganic minerals $+40 \%$ organic trace minerals. ${ }^{5}$ Non-significant

Means followed by * in the same column are different from the control treatment by the $t$ test at $5 \%$ probability level. 
Broilers fed the diet formulated on the ideal protein concept $(\mathrm{IP})$ reduced $(p<0.05) \mathrm{N}$ intake in $5.7 \%$, resulting in $13.1 \% \mathrm{~N}$ excretion reduction $(p<0.05)$ when compared to $\mathrm{C}$.

Average protein reduction in the total period was $1.3 \%$, with $10.3 \%$ less $\mathrm{N}$ excretion for each unit of dietary crude protein reduction. Similar results were obtained by De Faria \& Sakamoto (2008), who observed 9.9\% $\mathrm{N}$ excretion reduction when feeds based on the ideal protein concepts were used. However, Ferket (2002) reported $8.5 \%$ less $N$ excretion for each unit of dietary crude protein reduction.

The reduced-protein diet (IP) did not influence $(p>$ $0.05) \mathrm{N}$ retention ( $\mathrm{g} / \mathrm{bird}$ and $\%$ ) as compared to C. It was inferred that the feed formulated using the ideal protein concept presented better amino acid balance, as $\mathrm{N}$ excretion was reduced and $\mathrm{N}$ retention was maintained.

The diets supplemented with phytase $(\mathrm{C}+\mathrm{PHY})$ and inorganic-organic minerals $(C+M I N)$ did not affect $(p>$ $0.05) \mathrm{N}$ balance as compared to $C$.

The diet with the combination of different nutritional strategies (IP+PHY+MIN) resulted in lower $\mathrm{N}$ intake and retention, with 6.4 and $13.6 \%$ respectively. However, there was no difference $(p>0.05)$ in $N$ retention ( $\mathrm{g} / \mathrm{bird}$ and \%) when compared to $\mathrm{C}$. These results are consistent with the findings of De Faria \& Sakamoto (2008), who found that a feed containing a combination of these same nutritional strategies promoted lower $\mathrm{N}$ content in the excreta, but did not affect $\mathrm{N}$ retention.

Table 11 shows the results relative to phosphorus balance of broilers during the period of 1 to 21 days of age, submitted to different nutritional strategies

Table 11 - Phosphorus balance results of 1- to 21-d-old broilers submitted to different nutritional strategies

\begin{tabular}{lcccc}
\hline Treatment & $\begin{array}{c}\text { Pintake, g/ } \\
\text { bird }\end{array}$ & $\begin{array}{c}\text { Pexcretion, } \\
\text { g/bird }\end{array}$ & $\begin{array}{c}\text { P retention, } \\
\text { g/bird }\end{array}$ & $\begin{array}{c}\text { P retention, } \\
\%\end{array}$ \\
\hline Control (C') & 8.8 & 3.6 & 5.2 & 59.2 \\
$\mathrm{IP}^{2}$ & $8.3^{*}$ & 3.6 & $4.7^{*}$ & 56.8 \\
$\mathrm{C}+\mathrm{PHY}^{3}$ & $7.0^{*}$ & $2.7^{*}$ & $4.4^{*}$ & $62.0^{*}$ \\
$\mathrm{C}+\mathrm{MIN}^{4}$ & $9.0^{*}$ & 3.4 & $5.6^{*}$ & $62.3^{*}$ \\
$\mathrm{IP}+\mathrm{PHY}+\mathrm{MIN}^{*}$ & $6.7^{*}$ & $2.3^{*}$ & $4.4^{*}$ & $65.4^{*}$ \\
\hline ANOVA & 0.001 & 0.001 & 0.001 & 0.001 \\
\hline CV \% & 2.7 & 7.1 & 5.7 & 4.5 \\
\hline
\end{tabular}

${ }^{1} \mathrm{C}=$ Typical crude protein levels; ${ }^{2} \mathrm{P}=$ ideal protein; ${ }^{3 \mathrm{PHY}}=$ Phytase; ${ }^{4} \mathrm{Min}=50 \%$ inorganic minerals $+40 \%$ organic trace minerals.

Means followed by * in the same column are different from the control treatment by the $t$ test at $5 \%$ probability level.
Broilers fed the ideal protein diet (IP) presented lower $(p<0.05) P$ intake and retention, but there were no differences in $\mathrm{P}$ excretion ( $\mathrm{g} / \mathrm{bird}$ and \%) when compared with those fed the $C$ diet. Relative to the broilers receiving the control diet, those fed the diet with phytase $(\mathrm{C}+\mathrm{PHY})$ and with the combination of nutritional strategies (IP+PHY+MIN) presented lower ( $p$ $<0.05$ ) P intake (19.7 and 23.7\%) and excretion (25.4 and $35.2 \%)$, and consequently reduced $P$ retention in $g /$ bird $(p<0.05)$. This may be explained by the fact that these diets contained less dicalcium phosphate, demonstrating that phytase increased the availability of phosphorus retained as phytate $(p<0.05)$ as shown by the increase in $P$ retention efficiency ( $P$ retention, $\%)$ in 5.3 and $10.5 \%$, respectively. The results obtained with the diet containing phytase $(\mathrm{C}+\mathrm{PHY})$ are consistent with the findings of Lelis et al. (2007) and De Faria \& Sakamoto (2008), who observed lower P excretion when broilers were fed diets with phytase supplementation. Also, Silva (2004) found that, in addition of reducing $P$ excretion, phytase improved the efficiency of $\mathrm{P}$ retention. The results obtained with the combination of nutritional strategies $(\mathrm{IP}+\mathrm{PHY}+\mathrm{MIN})$, agree with those of De Faria \& Sakamoto (2008).

There was a reduction $(p<0.05)$ in $P$ intake when the feed was supplemented with inorganic-organic minerals $(C+M I N)$, but there was no effect $(p>0.05)$ on $\mathrm{P}$ excretion, resulting in higher $\mathrm{P}$ retention ( $\mathrm{g} / \mathrm{bird}$ and $\%)(p<0.05)$ when compared to the control diet.

Table 12 shows phosphorus balance of broilers during the period of 1 to 46 days of age submitted to different nutritional strategies.

Table 12 - Phosphorus balance results of 1- to 46-s-old broilers submitted to different nutritional strategies

\begin{tabular}{lllll}
\hline \multirow{2}{*}{ Treatment } & $\begin{array}{l}\mathrm{P} \text { intake, g/ } \\
\text { bird }\end{array}$ & $\begin{array}{l}\mathrm{P} \text { excretion, } \\
\text { g/bird }\end{array}$ & $\begin{array}{l}\text { P retention, } \\
\text { g/bird }\end{array}$ & $\begin{array}{l}\text { P retention, } \\
\%\end{array}$ \\
\hline Control (C $\left.\mathrm{C}^{1}\right)$ & 31.6 & 14.2 & 17.4 & 55.1 \\
$\mathrm{IP}^{2}$ & 30.9 & 13.7 & 16.7 & 54.2 \\
$\mathrm{C}+\mathrm{PHY}^{3}$ & $24.2^{*}$ & $9.1^{*}$ & $15.1^{*}$ & $62.5^{*}$ \\
$\mathrm{C}^{*} \mathrm{MIN}{ }^{4}$ & $30.3^{*}$ & 13.9 & 16.4 & 54.3 \\
$\mathrm{IP}+\mathrm{PHY}+\mathrm{MIN}$ & $21.3^{*}$ & $8.2^{*}$ & $13.1^{*}$ & $61.4^{*}$ \\
\hline ANOVA & 0.001 & 0.001 & 0.001 & 0.001 \\
\hline CV \% & 3.8 & 9.4 & 8.1 & 6.5 \\
\hline
\end{tabular}

${ }^{1} \mathrm{C}=$ Typical crude protein levels; ${ }^{2} \mathrm{P}=$ ideal protein; ${ }^{3} \mathrm{PHY}=$ Phytase; ${ }^{4} \mathrm{Min}=50 \%$ inorganic minerals $+40 \%$ organic trace minerals.

Means followed by * in the same column are different from the control treatment by the $t$ test at $5 \%$ probability level.

The ideal protein diet (IP) did not influence $(p>$ $0.05) \mathrm{P}$ balance relative to the $C$ diet. As compared to the control diet, those containing phytase $(\mathrm{C}+\mathrm{PHY})$ or the combination of nutritional strategies $(\mathrm{IP}+\mathrm{PHY}+\mathrm{MIN})$ 
had the same effect as in the period of 1 to 21 days of age, with lower $(p<0.05) P$ intake $(23.3$ and $32.5 \%)$, $P$ excretion (36.0 and 42.1\%), and retention in $\mathrm{g} /$ bird (13.0 and 24.6\%), respectively. However, higher $P$ retention efficiencies were obtained, with 13.5 and $11.4 \%$ respectively. The results obtained with the $\mathrm{C}+\mathrm{PHY}$ diet are consistent with those of Simons et al. (1990), Munaro (1996), Ferket et al. (2002), and Dari (2004), who found that phytase reduces $P$ excretion between 20 and $60 \%$ by increasing $P$ retention, whereas the effect of treatment IP+PHY+MIN are in agreement with the findings of De Faria \& Sakamoto (2008). There was a reduction $(p<0.05)$ in $P$ intake with the diet supplemented with inorganic-organic minerals $(C+M I N)$, but there was no effect $(p>0.05)$ in $P$ excretion, retention in $\mathrm{g} / \mathrm{bird}$ or in the efficiency of $P$ retention as compared to the birds fed the $C$ diet.

Table 13 shows calcium balance results of broilers during the period of 1 to 21 days of age, submitted to different nutritional strategies.

Table 13 - Calcium balance results of 1- to 21-d-old broilers submitted to different nutritional strategies

\begin{tabular}{|c|c|c|c|c|}
\hline Treatment & $\begin{array}{c}\text { Ca intake, } \\
\text { g/bird }\end{array}$ & $\begin{array}{c}\text { Ca } \\
\text { excretion, g/ } \\
\text { bird }\end{array}$ & $\begin{array}{l}\text { Ca } \\
\text { retention, } \\
\text { g/bird }\end{array}$ & $\begin{array}{c}\mathrm{Ca} \\
\text { retention, } \\
\%\end{array}$ \\
\hline Control $\left(C^{1}\right)$ & 11.9 & 5.2 & 6.7 & 56.0 \\
\hline $\mathrm{IP}^{2}$ & $12.4^{*}$ & 5.6 & 6.8 & 54.6 \\
\hline $\mathrm{C}+\mathrm{PHY}^{3}$ & $10.7^{*}$ & $4.6^{*}$ & 6.1 & 57.2 \\
\hline $\mathrm{C}+\mathrm{MIN}^{4}$ & $12.9 *$ & 5.3 & $7.6^{*}$ & 59.1 \\
\hline $\mathrm{IP}+\mathrm{PHY}+\mathrm{MIN}$ & 10.1 * & 4.8 & $5.3^{*}$ & 52.4 \\
\hline ANOVA & 0.001 & 0.001 & 0.001 & 0.001 \\
\hline CV \% & 2.70 & 8.93 & 7.90 & 7.34 \\
\hline LSM & 0.3 & 0.5 & 0.5 & 4.2 \\
\hline
\end{tabular}

${ }^{1} \mathrm{C}=$ Typical crude protein levels; ${ }^{2} \mathrm{P}=$ ideal protein; ${ }^{3} \mathrm{PHY}=$ Phytase; ${ }^{4} \mathrm{Min}=50 \%$ inorganic minerals $+40 \%$ organic trace minerals.

Means followed by * in the same column are different from the control treatment by the $t$ test at $5 \%$ probability level.

The feed formulated using the ideal protein concept (IP) promoted higher $(p<0.05)$ Ca intake, but maintained the same $(p>0.05)$ Ca excretion and retention ( $\mathrm{g} / \mathrm{bird}$ and $\%$ ) relative to $\mathrm{C}$ diet.

As compared to birds fed the $C$ diet, those receiving the diet with phytase $(\mathrm{C}+\mathrm{PHY})$ reduced $(\mathrm{p}<0.05) \mathrm{Ca}$ intake and excretion in $9.7 \%$ and $12.2 \%$ respectively, but there were no differences $(p>0.05)$ in $\mathrm{Ca}$ retention ( $\mathrm{g} / \mathrm{bird}$ or \%). These results are in agreement with Quian et al. (1997), according to whom, phytase supplementation has synergistic effect on $\mathrm{Ca}$ and $P$ utilization as it maintains the Ca:available $P$ ratio constant at 2:1 in the feed, reducing excretion, but not their retention by broilers.

Due to the increase in $(p<0.05)$ Ca intake of broilers fed the diet with inorganic-organic mineral supplementation $(\mathrm{C}+\mathrm{MIN})$, these birds presented higher Ca retention in $\mathrm{g} / \mathrm{bird}(\mathrm{p}<0.05)$, but had the same ( $p>0.05)$ Ca excretion and retention efficiency as compared to $\mathrm{C}$-fed broilers.

Ca intake was lower $(p<0.05)$ in broilers fed the combination of nutritional strategies (IP+PHY+MIN), resulting in $20.5 \%$ lower $(p<0.05)$ Ca retention in $g /$ bird relative to $C$, but the same $(p>0.05) C$ a excretion and retention efficiency.

Table 14 presents data relative to calcium balance of broilers during the period of 1 to 46 days of age, submitted to different nutritional strategies.

Table 14 - Calcium balance results of 1 - to 46 -d-old broilers submitted to different nutritional strategies

\begin{tabular}{|c|c|c|c|c|}
\hline Treatment & $\begin{array}{l}\text { Ca intake, } \\
\text { g/bird }\end{array}$ & $\begin{array}{c}\text { Ca } \\
\text { excretion, g/ } \\
\text { bird }\end{array}$ & $\begin{array}{l}\text { Ca } \\
\text { retention, } \\
\text { g/bird }\end{array}$ & $\begin{array}{c}\mathrm{Ca} \\
\text { retention, } \\
\%\end{array}$ \\
\hline Control (C') & 45.4 & 21.4 & 24.0 & 52.9 \\
\hline $\mathrm{IP}^{2}$ & 44.6 & 21.5 & 23.1 & 51.8 \\
\hline $\mathrm{C}+\mathrm{PHY}^{3}$ & $38.0 *$ & $17.4^{*}$ & $20.6^{*}$ & 54.2 \\
\hline $\mathrm{C}+\mathrm{MIN}^{4}$ & 45.0 & 22.0 & 23.0 & 51.2 \\
\hline $\mathrm{IP}+\mathrm{PHY}+\mathrm{MIN}$ & $35.4^{*}$ & $16.8^{*}$ & $18.6^{*}$ & 52.4 \\
\hline ANOVA & 0.001 & 0.001 & 0.001 & $n s^{5}$ \\
\hline CV \% & 3.5 & 10.2 & 9.4 & 8.7 \\
\hline
\end{tabular}

${ }^{1} \mathrm{C}=$ Typical crude protein levels; ${ }^{2} \mathrm{P}=$ ideal protein; ${ }^{3} \mathrm{PHY}=$ Phytase; ${ }^{4} \mathrm{Min}=50 \%$ inorganic minerals $+40 \%$ organic trace minerals. ${ }^{5}$ Not significant Means followed by * in the same column are different from the control treatment by the test at $5 \%$ probability level.

Ca balance in broilers fed diets using the ideal protein concept (IP) and with inorganic-organic mineral supplementation $(\mathrm{C}+\mathrm{MIN})$ when compared to those fed the control diet (C).

As compared to C-fed broilers, those birds receiving the diets with phytase $(\mathrm{C}+\mathrm{PHY})$ and with the combination of nutritional strategies (IP+PHY+MIN) reduced $(p<0.05)$ Ca intake in 16.2 and $21.9 \%$, resulting in lower $(p<0.05)$ Ca excretion (18.6 and $21.4 \%$ ) and Ca retention in g/bird (14.1 and $22.5 \%$ ), respectively. This occurred because, although these diets contained lower dicalcium phosphate content, phytase released $\mathrm{Ca}$ from phytic acid, making it available for absorption, resulting in the same 
Ca retention efficiency as that obtained with the control diet.

Table 15 shows the results of trace mineral $(\mathrm{Cu}$, $\mathrm{Mn}$ and $\mathrm{Zn}$ ) balance of broilers during the period of 1 to 21 days of age, submitted to different nutritional strategies.

Table 15 - Manganese, copper and zinc contents in the excreta of 1- to 21 -d-old broilers submitted to different nutritional strategies

\begin{tabular}{|c|c|c|c|}
\hline Treatment & $\begin{array}{c}\text { Copper } \\
\text { Excretion, mg/ } \\
\text { bird }\end{array}$ & $\begin{array}{l}\text { Manganese } \\
\text { Excretion, mg/ } \\
\text { bird }\end{array}$ & $\begin{array}{l}\text { Zinc } \\
\text { Excretion, mg/ } \\
\text { bird }\end{array}$ \\
\hline Control $\left(C^{1}\right)$ & 21.2 & 97.5 & 104.6 \\
\hline $\mathrm{IP}^{2}$ & 21.1 & 97.6 & $112.2^{*}$ \\
\hline $\mathrm{C}+\mathrm{PHY}^{3}$ & $19.5^{*}$ & 91.8 & $95.5^{*}$ \\
\hline $\mathrm{C}+\mathrm{MIN}^{4}$ & 21.3 & $88.9 *$ & 99.0 \\
\hline $\mathrm{IP}+\mathrm{PHY}+\mathrm{MIN}$ & $19.7 *$ & 89.1 * & $93.9 *$ \\
\hline ANOVA & 0.002 & 0.024 & 0.001 \\
\hline CV \% & 5.2 & 7.3 & 6.4 \\
\hline
\end{tabular}

${ }^{1} \mathrm{C}=$ Typical crude protein levels; $2 \mathrm{P}=$ ideal protein; ${ }^{3 \mathrm{PHY}}=$ Phytase; ${ }^{4} \mathrm{Min}=50 \%$ inorganic minerals $+40 \%$ organic trace minerals.

Means followed by * in the same column are different from the control treatment by the $t$ test at $5 \%$ probability level.

The diet formulated according to the ideal protein concept (IP) did not affect ( $p>0.05) \mathrm{Cu}$ or $\mathrm{Mn}$ excretion. However, higher $(p<0.05) \mathrm{Zn}$ excretion levels were obtained as compared to diet $C$. Once this feed did not contain enzymes or organic trace minerals, phytate possibly interacted with Zn, making it unavailable.

Although the diet containing phytase $(\mathrm{C}+\mathrm{PHY})$ did not affect ( $p>0.05)$ Mn excretion, it reduced $(p<0.05)$ $\mathrm{Cu}$ and $\mathrm{Zn}$ excretion in 8.1 and $8.7 \%$, respectively. Phytase hydrolyses phytate-mineral bonds, releasing Zn and Cu, as reported by Ravindran \& Bryden (1997). These results are consistent with those obtained by Sebastian et al. (1996) and by Ferket et al. (2002), who observed $8 \%$ reduction in $\mathrm{Zn}$ excretion when phytase was included in the diet.

The broilers fed the diet with inorganic-organic mineral supplementation $(C+M I N)$ reduced $(p<0.05)$ $\mathrm{Mn}$ excretion in $8.8 \%$, but $\mathrm{Cu}$ and $\mathrm{Zn}$ excretion was not affected ( $p>0.05$ ). Also Nollet et al. (2007) reported reduced $\mathrm{Cu}, \mathrm{Zn}$ and $\mathrm{Mn}$ excretion in broiler fed organic trace minerals, whereas De Faria \& Sakamoto (2008) did not obtain any reduction in $\mathrm{Cu}$, $\mathrm{Zn}$ and $\mathrm{Mn}$ excretion.
The use of the combination of nutritional strategies $(\mathrm{IP}+\mathrm{PHY}+\mathrm{MIN})$ reduced $(\mathrm{p}<0.05) \mathrm{Cu}, \mathrm{Mn}$, and $\mathrm{Zn}$ excretion in $7.1,8.6$ and $10.3 \%$, respectively.

Table 16 shows the results of trace mineral $(\mathrm{Cu}$, $\mathrm{Mn}$ and $\mathrm{Zn}$ ) balance of broilers during the period of 1 to 46 days of age, submitted to different nutritional strategies.

Table 16 - Manganese, copper and zinc contents in the excreta of 1- to 46-d-old broilers submitted to different nutritional strategies

\begin{tabular}{lccc}
\hline Treatment & $\begin{array}{c}\text { Copper } \\
\text { Excretion, mg/ } \\
\text { bird }\end{array}$ & $\begin{array}{c}\text { Manganese } \\
\text { Excretion, mg/ } \\
\text { bird }\end{array}$ & $\begin{array}{c}\text { Zinc } \\
\text { Excretion, mg/ } \\
\text { bird }\end{array}$ \\
\hline Control (C') & 78.9 & 406.8 & 468.3 \\
IP2 $^{2}$ & 78.0 & 377.1 & 451.0 \\
C+PHY & 72.2 & $358.1^{*}$ & 435.6 \\
C+MIN4 & 75.1 & $359.7^{*}$ & 436.3 \\
IP+PHY+MIN & 71.2 & $341.4^{*}$ & 412.9 \\
ANOVA & $n s^{5}$ & 0.005 & $n s$ \\
CV \% & 8.8 & 9.0 & 10.2 \\
\hline
\end{tabular}

${ }^{1} \mathrm{C}=$ Typical crude protein levels; ${ }^{2} \mathrm{P}=$ ideal protein; ${ }^{3} \mathrm{PHY}=$ Phytase; ${ }^{4} \mathrm{Min}=50 \%$ inorganic minerals $+40 \%$ organic trace minerals.

Means followed by * in the same column are different from the control treatment by the $t$ test at $5 \%$ probability level.

There was no significant difference in $\mathrm{Cu}, \mathrm{Mn}$ or Zn excretion in broilers fed the ideal protein diet (IP) relative to the control diet.

Broiler fed the diet containing phytase $(\mathrm{C}+\mathrm{PHY})$ reduced $(p<0.05)$ Mn excretion in $12.0 \%$ as compared to those fed the control diet (C). Phytase apparently has higher capacity to release $\mathrm{Mn}$ than the other trace minerals. According to Underwood \& Suttle (2001), phytase makes $\mathrm{Cu}, \mathrm{Zn}$ and $\mathrm{Mn}$ available by releasing them from phytate, thereby reducing their excretion. However, Ferket et al. (2002) observed only 5 to $8 \%$ Zn excretion reduction when phytase was added to the diet.

Broilers receiving the diet with inorganic-organic mineral supplementation $(\mathrm{C}+\mathrm{MIN})$ and that with the combination of nutritional strategies (IP+PHY+MIN) reduced $(p<0.05) \mathrm{Mn}$ excretion in 11.6 and $16.1 \%$, respectively, but there was no influence $(p>0.05)$ on $\mathrm{Cu}$ and $\mathrm{Zn}$ excretion when compared to the control diet.

These results are partially consistent with the findings of Ferket et al. (2002), who observed reduced $\mathrm{Cu}, \mathrm{Mn}$ and $\mathrm{Zn}$ excretion with the utilization of organic trace minerals, and with those of De Faria \& Sakamoto (2008), who did not obtain any differences in Cu and Mn excretion. It is possible that the inorganic trace minerals 
( $\mathrm{Cu}$ and $\mathrm{Zn}$ ) present both in the mineral supplement and in the feed were not absorbed due to the lack of intestinal transporters (metallothioneins) or to the antagonism between those elements. Underwood \& Suttle (2001) reported that trace mineral absorption is low in monogastric animals due to these factors.

\section{CONCLUSIONS}

The diets formulated using the ideal protein concept and the same principle plus inorganic-organic mineral supplementation allowed 13.6 and $13.1 \%$ nitrogen excretion reduction, respectively, and the same nitrogen retention ( $\mathrm{g} / \mathrm{bird}$ ) and retention efficiency as compared to the diet containing typical crude protein levels. Phytase supplementation reduced phosphorus, calcium, and manganese excretion and improved phosphorus retention. The inorganic-organic mineral supplementation to the diet reduced manganese excretion.

\section{REFERENCES}

Ammerman CB, Baker, DH, Lewis, AJ. Bioavailability of nutrients for animals. Amino Acids, Minerals and Vitamins. San Diego: Academic Press; 1995.

Dari RLA. Utilização de fitase na alimentação de aves. Conferencia APINCO de Ciência e Tecnologia Avícolas; 2004; Santos, São Paulo. Brasil. p.127-143.

De Faria DE, Sakamoto MI. Estratégias nutricionais para reduzir a excreção de nutrientes em frangos de corte. 5th Simpósio sobre Manejo e Nutrição de Aves e Suínos; 2008; Cascavel, Paraná. Brasil. p.81-8.

Ferket PR, Van Heugten E, Van Kempen TLTG, Angel R. Nutritional estrategies to reduce environmental emissions from nonruminants. Journal of Animal Science 2002;80(2):168-182.

Lan GQ, Abdullah N, Jalaludin S, Ho YW. Efficacy of supplementation of a phytase-producing bacterial culture on the performance and nutrient use of broiler chickens fed corn-soybean meal diets. Poultry Science 2002;81(10):1522-1532

Lelis GR, Albino LFT, Borsatto CG, Silva CR, Rostagno HS. Efeito da suplementação de fitase no metabolismo dos nutrientes em rações de frangos de corte. Conferencia APINCO de Ciência e Tecnologia Avícolas; 2007; Santos, São Paulo. Brasil. p.64.

Munaro FA, López J, Teixeira AS, Rutz F. Aumento da disponibilidade do fósforo fítico pela adição de fitase a rações para frangos de corte. Revista Brasileira de Zootecnia 1996; 5(5):921-931.

Nollet L, Van Der Klis JD, Lensing M, Spring P. The Effect of Replacing Inorganic With Organic Trace Minerals in Broiler Diets on Productive Performance and Mineral Excretion. Journal of Applied Poultry Research 2007;16(4):592-597.

Paterson PH. Hen house ammonia: Environmental consequences and dietary strategies. Multi-state poultry meeting; 2002; Pensilvânia, Pensilvânia. United State of America. p.12.

Payne VW. Management, treatment and utilization of poultry litter with respect to environmental protection. Simpósio Internacional sobre Ambiência e Sistemas de Produção Avícola; 1998; Concórdia, Santa Catarina. Brasil. p.182-193.
Quian $\mathrm{H}$, Kornegay ET, Denbow DM. Utilization of phytate phosphorus and calcium as influenced by microbial phytase, cholecalciferol, and the calcium:total phosphorus ratio in broiler diets. Poultry Science $1997 ; 76(7): 37-46$

Ravindran V, Bryden WL. Influence of dietary phytic acid and available phosphorus levels on the response of broilers to supplemental natuphos. Short course on feed technology; 1997; Ansung, Korean Society of Animal Nutrition and feedstuffs.

Rodrigues KF. Relação lisina digestível:proteína bruta em dietas para frangos de corte. [tese]. Lavras (MG): Universidade Federal de Lavras; 2006.

Rostagno HS, Albino LFT, Donzele JL, Gomes PC, Oliveira RF, Lopes DC, Ferreira AS, Barreto SLT. Tabelas brasileiras para aves e suínos: composição de alimentos e exigências nutricionais. 2 ed. Viçosa (MG): Universidade Federal de Viçosa; 2005.

Rutherfurd SM, Chung TH, Morel PCH, Moughan PJ. Effect of microbial phytase on ileal digestibility of phytase phosphorus, total phosphorus, and amino acids in a low-phosphorus diet for broilers. Poultry Science 2004;83(1):61- 68

Sebastian S, Touchburn SP, Chavez ER. Efficacy of supplemental microbial phytase at different calcium levels on growth performance and mineral utilization of broiler chickens. Poultry Science 1996:75(12):1516-1523.

Silva DJ. Análise de alimentos (métodos químicos e biológicos). Viçosa (MG): Universidade Federal de Viçosa; 1990.

Silva YL. Redução dos níveis de proteína e fósforo em rações com fitase para frangos de corte: desempenho, digestibilidade e excreção de nutrientes [tese]. Lavras (MG): Universidade Federal de Lavras; 2004.

Simons PC, Versteegh HA, Jongbloed AW, Kemme PA, Slump P, Bos KD, Wolters MG, Beudeker RF, Verschoor GJ. Improvement of availiability by microbial phytase in broilers and pigs. British Journal of Nutrition 1990;64:525-540

Underwood DJ, Suttle NF, editor. The Mineral Nutrition of Livestock. 3ed. Washington: CABI Publishing; 2001.

Universidade Federal de Viçosa. Sistema de análises estatísticas e genéticas - SAEG. Versão 8.0. Viçosa (MG); 2000

Viveiros A, Brenes A, Arija IC, Centeno C. Effects of microbial phytase supplementation on mineral utilization and serum enzyme activities in broiler chicks fed different levels of phosphorus. Poultry Science 2002; 81(8):1172- 1183 